\title{
EKSEKUSI JAMINAN FIDUSIA KARENA OVERMACHT (STUDI DI WAHANA OTTOMITRA MULTIARTHA FINANCE MATARAM)
}

\author{
Lalu Indra Wijaya \\ Magister Kenotariatan Universitas Mataram \\ Email: laluindrawijaya007@gmail.com
}

\begin{abstract}
Abstrak
Penelitian ini bertujuan untuk mengkaji dan menganalisa Eksekusi Terhadap Jaminan Fidusia Karena Overmacht, faktor-faktor yang mempengaruhipelaksanaanEksekusi TerhadapJaminan Fidusia Akibat Overmacht di PT. Wahana Ottomitra Multiartha Finance Mataram. Eksekusi Obyek Jaminan Fidusia Yang oleh PT. Wom Finance Kota Mataram Dilakukan Melalui beberapa Prosedur/Tahapan, penugasan Remidial Field dan Dept Collector sampai dengan pemberian fasilitas sebagai solusi bagi para konsumen (penerima fasilitas). Terkait dengan proses eksekusi ini, pengambilan yang dilakukan oleh Dept Collector (DC) ini tidak membedakan penyebab terjadinya kredit macet, baik itu karna wanprestasi maupun karna overmacht, karna Remedial Field dan Dept Collector (DC) setelah menerima penugasan dari remedial di atas langsung mendatangi alamat yang ada dalam data remedial card untuk mengambil kembali barang jaminan untuk dilakukan penarikan. Berdasarkan keterangan dari Litigation Dept. Head PT. WOM Finance Cabang Mataram, hambatan yang seringkali dialami adalah ketika barang jaminan sudah berpindah tangan, tanpa persetujuan tertulis dari PT. WOM Finance Kota Mataram.
\end{abstract}

Kata Kunci : Eksekusi, Fidusia, Overmacht 


\section{A. Pendahuluan}

Pembangunan ekonomi sebagai bagian dari pembangunan Nasional merupakan salah satu upaya untuk mewujudkan kesejahteraan rakyat yang adil dan makmur berdasarkan Pancasila dan Undang-Undang Dasar 1945, Dalam rangka dan meneruskan pembangunan baik pemerintah maupun masyarakat, baik perseorangan maupun badan hukum memerlukan dana besar. Seiring dengan meningkatnya pembangunan, meningkat pula kebutuhan terhadap pendanaan, yang sebahagian besar dana yang diperlukan untuk memenuhi kebutuhan tersebut melalui pinjam-meminjam. ${ }^{1}$

Utang piutang merupakan suatu perbuatan yang tidak asing lagi bagi masyarakat kita pada masa sekarang ini.Utang piutang tidak hanya dilakukan oleh orang-orang yang ekonominya lemah, tetapi juga dilakukan oleh orang-orang yang ekonominya relatif mampu. Suatu utang diberikan terutama atas integritas atau kepribadian debitor, kepribadian yang menimbulkan rasa kepercayaandalamdirikreditor,bahwa debitor akan memenuhi kewajiban pelunasannya dengan baik. Akan tetapi juga suatu ketika nampaknya keadaan keuangan seseorang baik, belum menjadi jaminan bahwa

${ }^{1}$ Purwahid Patrik dan Kashadi, Hukum Jaminan, , Fakultas Hukum, Universitas Diponegoro, Semarang, 2008, hlm. 32. nanti pada saat jatuh tempo untuk mengembalikan pinjaman, keadaan keuangannya masih tetap sebaik keadaan semula. $^{2}$

Selanjutnya untuk menampung kebutuhan masyarakat, perkembangan ekonomi, dan perkembangan perkreditan dalam masyarakat Indonesia sekarang ini memerlukan bentuk-bentuk jaminan pembiayaan, di mana orang memerlukan kredit dengan jaminan barang bergerak, namun tersebut masih tetap dapat menggunakannya untuk keperluan sehari-hari maupun untuk keperluan usahanya, jaminan kredit yang demikian tidak dapat ditampung hanya oleh peraturanperaturan gadai, yang tidak memungkinkan benda jaminan tersebut tetap berada pada yang menggadaikan, mengingat ketentuan dalam pasal 1152 ayat (2) $\mathrm{KUH}$ Perdata, yang mensyaratkan bahwa benda-benda bergerak berwujud yang diberikan sebagai jaminan berupa gadai harus berpindah dan berada dalam kekuasaan yang berpiutang, sedang barang-barang tersebut sangat diperlukan oleh yang bersangkutan menjalankan usahanya.

Pasal 1338 KUH Perdata sebagai dasar hukum adanya "kebebasan berkontrak" membuka kemugkinan untuk itu, dengan batas waktu perjanjian tersebut tidakbertentangan

${ }^{2} J$. Satrio, Hukum Jaminan, Hak-hak Kebendaan, Citra Aditya Bakti, Bandung, 1991, hlm. 97. 
undang-undang, ketertiban umum, kesusilaan. Atas dasar itu maka suatu perjanjian yang berlandaskan penyerahan milik atas suatu benda sebagai jaminan, merupakan suatu perjanjian untuk memberikan jaminan.Yang berpiutang (kreditor) menjadi pemilik dari benda itu sebagai demikian pada hakikatnya mempuyai kedudukan yang lebih kuat dari seorang pemegang gadai.Apabila yang berutang melunasi utangnya itu, maka milik benda itu masih beralih kembali kepada pemilik benda yang berutang dan yang berpiutang untuk mengembalikan benda itu kepada yang berutang. Oleh karena itu, guna memenuhi kebutuhan tersebut dan untuk memberikan kepastian hukum kepada para pihak yan berkepentingan, maka disahkannya Undang-undang Nomor 42 tahun 1999 tentang jaminan Fidusia yang diundangkan pada tanggal 30 september 1999 dan diumumkan dalam Lembaran Negara Republik Indonesia Tahun 1999 Nomor 168 yang dirumuskan sebagai penyerahan hak milik atas dasar kepercayaan.

Sehubungandenganpenjaminan ini, apa yang harus dilakukan oleh penerima fidusia (kreditor) apabila pemberi fidusia (debitor) melalaikan kewajibannya atau cidera janji yang berupa lalainya pemberi fidusia (debitor) memenuhi kewajibannya pada saat pelunasan utangnya sudah matang untuk ditagih, maka dalam peristiwa seperti itu, penerima fidusia (kreditor) bisa melaksanakan eksekusinya atas benda jaminan fidusia. $^{3}$

Salah satu ciri dari jaminan utang kebendaan yang baik adalah apabila dapat eksekusinya secara cepat dengan proses sederhana, efisien dan mengandung kepastian hukum. Misalnya ketentuan eksekusi fidusia di Amerika Serikat yang membolehkan pihak kreditur mengambil sendiri objek jamianan fidusia asal dapat dihindari perkelahian/percekcokan (breaking the peace).Barang tersebut boleh dijual dimuka umum atau dibawah tangan asalkan dilakukan dengan itikad baik. ${ }^{4}$

Oleh karena itu penetapan besaran uang muka ini merupakan upaya pemerintah untuk meminimalisir sumber-sumber kerawanan dan resiko yang mungkin timbul, termasukpertumbuhan kredit atau pembiayaan kendaraan bermotor yang berlebihan. ${ }^{5}$ Mengingat semakin ketatnya persaingan antar perusahaan pembiayaan dengan dealer kendaraan bermotor, banyak ditemukan

${ }^{3}$ Ibid, hlm. 319.

${ }^{4}$ Munir Fuady, Jaminan Fidusia, PT. Citra aditya, Bandung, 2000, hlm. 57.

5 Stianto Trimulyo, Pelaksanaan perjanjian Pembiayaan Konsumen Dan Implikasi Wanprestasi Terhadap Obyek Jamninan (Studi Kasus di PT OTO Multiartha Finance Cabang Mataram). Vol 5 No 1 tahun 2017,http://jurnalius.ac.id/ojs/index.php/ jurnalIUS/issue/view/34, diakses tanggal 02 September 2017. 
pelanggaran yang dilakukan oleh perusahaan pembiayaan dengan dealer terhadap peraturan perundangundanganan yang berlaku, sehingga dikhawatirkan meningkatnya kredit macet dikarenakan kurang memperhatikan kapasitas konsumen, maka perlu diperhatikan bagaimana penerapan peraturan yang mengatur hal tersebut.

Tentu saja fidusia sebagai salah satu jenis jaminan utang juga harus memiliki unsur-unsur cepat, murah, dan pasti tersebut. Sebab selama ini (sebelum keluarnya Undang-undang Fidusia Nomor 42 Tahun 1999) tidak ada kejelasan bagaimana caranya mengeksekusi fidusia, sehingga tidak ada ketentuan yang mengaturnya, banyak yang menafsirkannya bahwa eksekusi fidusia adalah memakai prosedur gugatan biasa(lewat pengadilan dengan prosedur biasa) yang panjang, mahal dan melelahkan itu. ${ }^{6}$

Eksekusi terhadap benda yang menjadi objek jaminan fidusia dapat dilakukan dengan cara :

1. Pelaksanaan eksekusi.

2. Penjualan benda yang menjadi objek jaminan fidusia ataskekuasaan penerima fidusia itu sendiri melalui pelelangan umumserta mengambil pelunasan piutang dari hasil penjualan.

${ }^{6} I b i d$, hlm. 57.
3. Penjualan dibawah tangan yang dilakukan berdasarkan kesepakatan pemberi dan penerima fidusia jika dengan carademikian dapat diperoleh harga tinggi yang menguntungkan para pihak.

Jadi prinsipnya adalah bahwa penjualan benda yang menjadi objek jaminan fidusia dapat dilakukan melalui lelang suatu lelang dimuka umum dan dimungkinkan juga dilakukan penjualan dibawah tangan, asalkan hal tersebut disepakati oleh pemberi dan penerima fidusia. ${ }^{\text {? }}$

Dengan demikian, lembaga jaminan perlu mendapat perhatian serius sehubungan dengan pelaksanaan eksekusi jaminan fidusia dalam praktek kehidupan masyarakat dalam rangka pembangunan Indonesiakhususnya dibidanghukum, karena perkembangan ekonomi dan khususnya dibidang hukum, karena perkembangan ekonomi dan perdangan akan selalu diikuti oleh perkembangan kebutuhan akan kredit.

Berdasarkan hasil pengamatan penulis, eksekusijaminanfidusiasering terjadi kesulitan dalam hal barang jaminan berupa kendaraan bermotor roda dua sudah dipindahtangankan, identitas barang jaminan diubah, debitor pindah alamat dan bahkan

${ }^{7}$ Gunawan Widjaja dan Ahmad Yani, Jaminan Fidusia, PT. Grafindo Persada, Jakarta , 2000, hlm. 52. 
terjadinya keadaan memaksa, yakni keadaan tidak dapat dipenuhinya prestasi oleh pihak debitur karena terjadi suatu peristiwa bukan karena kesalahannya, peristiwa mana tidak dapatdiketahuiatautidakdapatdiduga akan terjadi pada waktu membuat perikatan, yang dikenal dengan istilah Overmacht. Seperti kasus yang dialami oleh salah seorang debitur yakni Tuan Ibrahim (selanjutnya disebut pihak debitur) yang beralamat di Dusun Montong Desa Selat Kecamatan Narmada, melakukan perjanjian kredit kendaraan bermotor dengan PT. WAHANA OTTOMITRA MULTIARTHA Cabang Mataram berupa 1 unit sepeda motor.Seiring perjalanan waktu pada angsuran ke 15 pada bulan Juni 2015, pihak debitur menalami keterlambatan membayar angsuran hingga 70 hari atau biasa dikatakan sudah melawati bulan ke 3 dan akhirnya kasus tuan Ibrahim ditangani oleh divisi Remidial PT Wahana Ottomitra MultiArtha yaitu bagian yang menangani bagian pencabutan kendraan motor yg sudah melewati 3 bulan. Tepat pada tanggal 20 September pihak keluarga dari Tuan Ibrahim yaitu Tuan Arifin Jayadi datang ke kantor untuk memberikan klarifikasi bahwa pada bulan Juli tuan Ibrahim sedang mengalami musibah yaitu mengalami musibah tertimpa pohon pada saat ingin ke kantor WOM Finance cabang Mataram untuk melakukan pembayaran kridit sepeda motor.

\section{B. PEMBAHASAN}

1. Eksekusi Jaminan Fidusia Di PT. Wahana Ottomitra Multiartha Finance Kota Mataram

a) Pengambilan kembali barang jaminan

Eksekusi menurut Pasal 29 Undang-undang Nomor 42 tahun 1999, eksekusiadalah pelaksanaan titel eksekutorial oleh Penerima Fidusia, berarti eksekusi langsung dapat dilaksanakantanpamelaluipengadilan dan bersifat final serta mengikat para pihak pelaksanaan eksekusi jaminan fidusia berdasarkan titel eksekutorial adalah benda yang dibebani dengan Jaminan Fidusia wajib didaftarkan sesuai Pasal 11 ayat (1) Undangundang Nomor 42 tahun 1999 tetang Jaminan Fidusia, pembebanan dimaksud adalah diatur dalam Pasal 5 ayat (1) "pembebanan dengan fidusia dibuat dengan akta notaris dalam bahasa Indonesia dan merupakan akta jaminan fidusia" lebih lanjut dalam Pasal 37 ayat (3) Jika dalam jangka waktu sebagaimana dimaksud dalam ayat (2) tidak dilakukan penyesuaian, maka perjanjian Jaminan Fidusia tersebut bukan merupakan hak agunan atas kebendaan sebagaimana dimaksud dalam Undang-undang Nomor 42 tahun 1999 dan tidak mempunyai titel eksekutorial 
berdasarkan SertifikatJaminan Fidusia sebagaimana dimaksud dalam Pasal 15 ayat (1) dicantumkan kata-kata "DEMI KEADILAN BERDASARKAN KETUHANAN YANG MAHA ESA".

Pasal 4 Undang-undang Jaminan Fidusia nomor 42 tahun 1999, menentukan bahwa, "Jaminan Fidusia yang merupakan perjanjian ikutan dari suatu perjanjian pokok bukan kewajiban bagi para pihak untuk memenuhi suatu prestasi", yang merupakan uraian tentang Identitas Pihak Pemberi dan Penerima Fidusia, data perjanjian pokok yang dijamin fidusia, uraian mengenai Benda yang menjadi objek Jaminan Fidusia, nilai penjaminan dan nilai benda yang menjadi objek jaminan Fidusia, yang dalam pendaftaran fidusia dilakukan oleh Penerima Jaminan / Penerima Fidusia untuk di daftarkan ke Kantor Pendaftaran Fidusia di Wilayah kerja Kantor Pendaftaran Fidusia di Kantor Wilayah Departemen Hukum dan Hak Azasi Manusia Provinsi Nusa Tenggara Barat.

Hal tersebut ditegaskan dalam Pasal 13 tentang Perjanjian Pemberian Jaminan Fidusia yang dikatakan bahwa "Biaya yang berkenaan dengan pembuatan perjanjian ini maupun dalammelaksanakan ketentuan dalam perjanjian ini menjadi tanggungan dan harus dibayar Penerima Fasilitas / Pemberi Jaminan, demikian pula biaya pendaftaran fidusia ini di Kantor Pendaftaran Fidusia”. Dengan tidak memenuhi ketentuan dalam Undangundang Nomor 42 tahun 1999 tentang Jaminan Fidusia, maka Perjanjian Pemberian Jaminan Fidusia yang disediakan dan yang ditanda-tangani oleh Pemberi Fasilitas / Penerima Fasilitas hanya sebagai akta dibawah tangan, yang tidak membatalkan Perjanjian Pokok yaitu Perjanjian Pembiayaan Konsumen.

Dalam Perjanjian Pembiayaan Konsumen PT. WOM Finance menegaskan bahwa "Ketentuan jaminan tersebut akan diatur secara terpisah dalam Perjanjian Pemberian Jaminan Fidusia yang dibuat dalam bentuk dan cara yang ditentukan oleh Pemberi Fasilitas, yang merupakan satu kesatuan dan bagian yang tidak terpisahkan dari perjanjian ini", dengan pembuatan perjanjian pokok tentang hutang atau kredit tersebut yang menimbulkan hak dan kewajiban antara dengan Penerima Fasilitas dapat dibuat secara di bawah tangan atau dibuat oleh Notaris harus dipatuhi oleh Penerima Fasilitas, sebagaimana diatur pada Pasal 5 ayat (1) Undang-undang Fidusia Nomor 42 tahun 1999, "Dalam rangka pembuatan akta pembebananjaminan fidusia dibuat dengan akta Notaris dan dalam bahasa Indonesia". ${ }^{8}$

Dengan memperhatikan Pasal tersebut diatas walau tidak dibuat dengan akta Notaris dan tidak

${ }^{8}$ Undang-undang Nomor 42 Tahun 1999 tentang Jaminan Fidusia. 
didaftarkan ke Kantor Pendaftaran Fidusia, istilah eksekusi tetap melekat pada pengambilan kembali barang jaminan sepeda motor akibat terjadinya wanprestasi penerima fasilitas. Pasal 196 HIR dan Pasal 208 Rbg "Eksekusi membayar sejumlah uang", baik dari tangan penerima fasilitas maupundaripihaklain, kecuali barang jaminan tersebut dijadikan barang bukti dalam pengadilan. ${ }^{9}$

Ketentuan Undang-undang Nomor 42 tahun 1999 tentangJaminan Fidusia tidak terpenuhi, demikian pula ketentuan sebagaimana yang terdapatdalam Perjanjian Pembiayaan Konsumen dan Perjanjian Pemberian Jaminan Fidusia Kota Mataram atas jaminan kebendaan tersebut menurut Hasil Penelitian penulis dilapangan tidak terpenuhi. Dengan demikian pulabahwapenjaminankebendaannya hanya berlaku ketentuan yang tunduk pada Pasal 1131 KUHPerdata.

Dasar hukum sita jaminan adalah Pasal 227 ayat (1) RBG atau Pasal 720 RV yang menyebutkan membolehkan penyitaan barang debitor selama belum dijatuhkan putusan akhir, dengan tujuan agar barang tersebut tidak digelapkan atau tidak dihilangkan debitor, selama proses persidangan berlangsung. Dengan demikian, pada saat putusan dilaksanakan, pelunasan pembayaran

${ }^{9}$ Sudikno Mertokusumo, Hukum Acara Perdata Indonesia, Liberty, Jogyakarta1998, hlm.27. utang yang dituntut dapat dipenuhi dengan menjual lelang (executoriale verkoop) barang sitaan itu.

b) Langkah-langkah sebelum mengambil kembali barang jaminan

Menurut Raden Adi Nugroho, Kepala Cabang PT. WOM Finance "adalah Proses Desk Call atau menelpon customer untuk memberitahukan tentang waktu pembayaran angsuran yang telah jatuh tempo, mengunjungi customer untuk mengingatkan (bagi yang tidak punya telepon), melakukan penagihan, mengirimkan surat peringatan 1 (satu) dan 2 (dua)". ${ }^{10}$

c) Penugasan Remedial Field dan Dept Collector (DC)

Menurut Jasli, selaku Litigation Dept. Head PT. WOM Finance, setiap pagi hari, Remedial Field dan Dept Collector (DC) menerima penugasan dari remedial yang disertai/dibekali dengan berkas sebagai berikut :

a. Dokumen primer

1) Surat Tugas untuk Remedial Field atau Surat Kuasa Penarikan Kembali.

2) Surat Berita acara serah terima barang jaminan (BASTBJ)

b. Dokumen optional adalah dokumen yang diadakan untuk

${ }^{10}$ Wawancara dengan Raden Adi Nugroho, Kepala Cabang PT. WOM Finance, senin 15 Mei 2017 
mendukung kelancaran kerja Remedial Field, sesuai dengan kondisi daerah masing-masing, anatara lain : ${ }^{11}$

1) Copy kontrak (Perjanjian Pemberian Konsumen, Perjanjian Pejanjian Pemberian Jaminan Fidusia);

2) Data A/R Card (Jadwal pembayaran angsuran);

3) Data Remedial Card (Data motor dan Penerima fasilitas);

4) Daftar kunjungan Remedial field.

Menurut Jasli. Litigation Dept. Head PT. WOM Finance "selain dari karyawan lapangan Remedial Field PT. WOM Finance Kota Mataram bekerjasama dengan pihak luar untuk membantu penyelesaian kredit bermasalah tersebut bentuknya adalah memeberikan kuasa kepada individu atau institusi-institusi seperti lawyer untuk mengambil dan atau menyelesiakan kredit bermasalah tersebut". ${ }^{12}$

Hasil penelitian penulis dilapangan terlihat bahwa indinviduindividu yang dimaksud adalah orang-perorang yang mempunyai kemampuan dalam negosiasi, pengaruh, disegani pada daerah-

${ }^{11}$ Ibid

${ }^{12}$ Wawancara dengan Jasli, Litigation Dept. Head PT. WOM Finance Cabang Mataram, Pada 13 Mei 2017. daerah tertentu, ulet dan dapat dipercaya, dengan mendapat surat kuasa yang selanjutnya disebut Penerima Kuasa dan di lapangan lebih kenal dengan dept collecktor (DC) dari PT. WOM Finance Kota Mataram untuk melakukan pengambilan kembali barang jaminan.

d) Pelaksanaan pengambilan kembali barang jaminan.

Setelah menerima kasus pelimpahan khusus atau pelimpahan otomatis surat tugas/surat kuasa, dokumen primer dan optional, Remedial field atau DC dari dept remedial, tersebut langsung mendatangi alamat yang ada dalam data remedial card untuk mengambil kembali barang jaminan menarikan jika barang jaminan ada maka langsung diambil dan dibawa ke Kantor WOM Finance Kota Mataram (jika dalam area kerja PT. WOM Finance Mataram), sedangkan apabila barang jaminan tidak ada atau sudah dialihkan maka Remedial field atau DC akan meminta penerima fasiltas menjelaskan kenapa barang jaminan dialihkan, "meminta dan melibatkan penerima fasilitas menunjuk kemana barang jaminan dialihkan untuk kemudian sesuai perjanjian diminta untuk menyerahkan barang jamian tersebut". ${ }^{13}$

${ }^{13}$ Wawancara dengan Amiruddin, Debt Collector. WOM Finance, Rabu 13 Mei 2017 
Menurut Amiruddin, kasus yang demikian tidak mudah dilakukan penarikan, karena pengalihan bukan atas dasar pinjaman semata tapi bisa karena dijual, digadai atau barang jaminan sudah keluar dari wilayah kerja PT. WOM Finance Kota Mataram, bahkan keluar dari Pulau Lombok. ${ }^{14}$ Apabila barang jaminan dialihkan masih dalam wilayah kerja PT. WOM kota Mataram, maka Remedial field atau DC mendatangi pemegang terakhir barang jaminan dan memberikan penjelasan kenapa barang jaminan tersebut hendak dilakukan penarikan disertai dengan menunjukan dokumen-dokumen tesebut di atas, Remedil field atau DC menerima penyerahan kendaraan sepeda motor dari Penerima fasilitas maka di buatkan Berita acara serah terima barang jaminan (BASTBJ) kemudian barang jaminan langsung bawa ke kantor PT. WOM Finance Kota Mataram.

Menurut Pasal 197 ayat (5) HIR atau Pasal 209 ayat (4) RBG Pejabat yang menjalankan eksekusi diperintahkan secara tegas untuk membuat "berita acara" eksekusi. Keabsahan formal eksekusi hanya dapat dibuktikan dengan berita acara, menjalankan eksekusi ini harus dituangkan dalam berita acara dan harus disaksikan dan ditandatangani oleh pihak yang menjalankan eksekusi dan dua orang saksi dianggap tidak

${ }^{14}$ Ibid sah, karena belum memenuhi syarat formal cara menjalankan eksekusi. Apalagi keikusertaan tereksekusi menandatangani sangat penting artinya, sebagai alat untuk mematahkan tuduhan dikemudian hari".

Setelah pengambilan kembali menurut Jasli, Litigation Dept. Head PT. WOM Finance "menjadi prosedur wajib yang harus dilakukan oleh petugas WOM internal ataupun eksternal untuk membuat Berita Acara Serah Terima Barang Jaminan (BASTBJ) , baik dari penerima fasilitas atau pihak ke-3, apabila yang menyerahkan barang jaminan tidak mau menandatangani Berita acara serah terima barang jaminan maka, dalamberita acara serah terimabarang jaminan tersebut diberi keterangan, bahwa yang menyerahkan tidak mau menandatangani bukti serah terima barangjaminan (BASTBJ), dan sebagai catatan dalam surat bukti serah terima barang jaminan (BASTBJ) tersebut yang menyerahkan/ customer barang jaminan di mohon agar menyelesaikan di kantor WOM selambat-lambatnya 7 (tujuh) hari kerja setelah tanggal penyerahan barang jaminan tersebut danpenerima fasilitas dapatmemohon perpanjangan waktu selama 6 (enam) hari kerja, ini diberikan terkait kebijakan apabila customer ada permasalahan atau musibah.

Apabila barang jaminan diketahui dengan jelas berada luar 
wilayah PT. WOM Finance Kota Mataram, maka Dept Remedial PT. WOM Finance Kota Mataram akan meminta bantuan Dept Remedial kantor cabang PT. WOM Finance setempat (PT.WOM memiliki 245 kantor cabang yang langsung melayani 1.400 dealer berbagai jenis merek kendaraan sepeda motor serta 276 pusat layanan.

Berdasarkan hasil penelitian penulis dilapangan, pengambilan yang dilakukan oleh Dept Collector (DC) ini tidak membedakan penyebab terjadinya kredit macet, baik itu karna wanprestasi maupun karna overmacht, karna Remedial Field dan Dept Collector (DC) setelah menerima penugasan dari remedial yang disertai/dibekali dengan dokumen primer dan dokumen optional yang telah dijelaskan di atas langsung mendatangi alamat yang ada dalam data remedial card untuk mengambil kembali barang jaminan untuk dilakukan penarikan.

Hal tersebut sama seperti kejadian yang dialami oleh salah seorang debitur yakni Tuan Ibrahim yang telah melakukan perjanjian kredit kendaraan bermotor dengan PT.Wahana Ottomitra Multiartha Cabang Mataram berupa 1 unit sepeda motor ketika DC melakukan penarikan kendaraan bermotor yang dijadikan jaminan tersebut. Sehingga pada tanggal 19 September 2015 Debt Collector di bawah naungan divisi remedial PT Wahana Ottomitra Multiartha Finance Cabang Mataram mendapatkan kendaraan tersebut berada di sebuah bengkel di daerah Cakranegara sehingga dengan gerak cepat Debt Collector melakukan pencabutan kendaraan dengan menunjukan surat tugas pencabutan kendraan bermotor dan akhirnya motor itu di bawa ke kantor untuk di selesaikan.

Beberapa waktu setelah dilakukan penarikan oleh pihak kreditur, pihak keluarga dari Tuan Ibrahim yaitu Tuan Arifin Jayadi datang ke kantor untuk memberikan klarifikasi bahwa tuan Ibrahim selaku debitur mengalami musibah tertimpa pohon pada saat ingin ke kantor WOM Finance cabang Mataram untuk melakukan pembayaran kridit sepeda motor.

Berdasarkan kejadian tersebut, Tuan Ibrahim selaku debitur seharusnya bebas dan lepas dari kewajibanmembayargantirugikarena berada dalam keadaan "overmacht", dimana prinsip dasar dari overmacht itu adalah menghalangi/ merintangi debitur melaksanakan pemenuhan prestasi. Akan tetapi, pada tanggal 19 September 2015 Debt Collector di bawah naungan Divisi Remedial PT WahanaOttomitraMultiarthaFinance Cabang Mataram mendapatkan kendaraan tersebut berada di sebuah bengkel di daerah Cakranegara sehingga dengan gerak cepat Debt 
Collector melakukan pencabutan kendaraan dengan menunjukan surat tugas pencabutan kendraan bermotor dan akhirnya motor itu di bawa ke kantor untuk di selesaikan.

Apa yang dialami oleh Tuan Ibrahim telah memenuhi unsur Overmacht, sehingga pihak PT. WOM Finance melalui Debt Collectornya harusnya tidak melakukan penarikan terhadap barang jaminan yang dimiliki oleh Tuan Ibrahim, karna peristiwa tersebut bertentangan dengan prinsip Overmacht, juga dalam ketentuan yang telah tertuang dalam KUH Perdata Pasal 1244 KUH Perdata berbunyi: "Jika ada alasan untuk itu, si berutang harus dihukum mengganti biaya, rugi dan bunga apabila ia tak dapat membuktikan, bahwa hal tidak atau tidak pada waktu yang tepat dilaksanakannya perikatan itu, disebabkan suatu hal yang tak terduga, pun tak dapat dipertanggungjawabkan padanya, kesemaunya itu pun jika itikad buruk tidaklah ada pada pihaknya". Selanjutnya Pasal 1245 KUH Perdata berbunyi: "Tidaklah biaya rugi dan bunga, harus digantinya, apalagi lantaran keadaan memaksa atau lantaran suatu kejadian tak disengaja si berutang beralangan memberikan atau berbuat sesuatu yang diwajibkan, atau lantaran hal-hal yang sama telah melakukan perbuatanyang terlarang.

Hal tersebut penulis katakana sebagai tidakan yang melampaui wewenang karena tepat pada tanggal 20 September pihak keluarga dari Tuan Ibrahim yaitu Tuan Arifin Jayadi datang ke kantor untuk memberikan klarifikasi bahwa yaitu pada bulan 27 Juli tuan Ibrahim sedang mengalami musibah yaitu mengalami musibah tertimpa pohon pada saat ingin ke kantorWOMFinancecabangMataram untuk melakukan pembayaran kridit sepeda motor. Tapi karena ada musibah tersebut maka pembayaran tersebut menjadi tersendat hingga menunggak menjadi 3 bulan karna dana yang dimiliki oleh Tuan Ibrahim digunakan untuk biaya rumah sakit.

e) Proses Lanjut Setelah Proses Penarikan Barang Jaminan

Remedial field atau DC wajib menyerahkan Unit kendaraan hasil penarikannya ke kantor WOM dalam waktu 1 x 24 jam, dan memberikan laporan atas hasil kujungan berdasarkan surat tugas atau surat kuasa yang diterimanya. Setelah barang jaminan tiba di kantor WOM, Remedial akan mengirimkan surat pemberitahuan ke penerima fasilitas untuk untuk melunasi seluruh hutangnya di WOM tenggang waktu yang diberikan 7 (tujuh) hari dari tanggal penyerahan kendaraan dan Penerima fasilitas dapat memohon perpanjangan waktu selama 6 (enam) hari kerja.

Namun dalam waktu 7 (tujuh) di tambah dengan 6 (enam) hari berikutnya, ada dua proses yang 
diberikan oleh pemberi fasilitas kepada penerima fasilitas yaitu :

f) Proses Pelunasan

Apabila penerima fasilitas bersedia untuk melakukan pelunasan hutangnya setelah kendaraan ditarik atau setelah setelah proses negosiasi dengan remedial field, maka penerima fasilitas membawa KTP asli dan copy berita acara serah terima barang jaminan (BASTBJ) untuk diserahkan keRemedialdikantorWOMRemedial meminta AR untuk mengeluarkan print out Draft Pelunasan.

g) Proses BTCA Komite (Back To Current A R)

BTCA adalah diperbolehkannya penerima fasilitas yang telah wanprestasi untuk melakukan pembayaran angsuran seperti biasanya dengan persetujuan Back to current AR Komite. Back to current AR diperbolehkan dengan alasan yang dapat diterima oleh komite, antara lain musibah/sakit/ kecelakaan yang dialami penerima fasilitas yang membutuhkan biaya sehingga penerima failitas tidak mampu membayar angsuran secara temporary.

Adapun yang penerima fasilitas yang tidak mendapat kebijakan sampai batas waktu yang diberikan selama 7 (tujuh) hari, yaitu berupa Back to current AR, maka salah satu jalan adalah pelunasan total seluruh angsuran, di tambah denda (yang timbul dari tidak dibayarkannya angsuran setiap tanggal jatuh tempo) dan biaya penarikan Apabila penerima faslitas dapat melakukan pelusanan total maka perjanjian berakhir, barang jaminan akan diserahkan kembali kepada penerima fasilitas disertai BPKB (Buku kepemilikan kendaraan bermotor), sebaliknya jika penerima fasilitas tidak sanggup melakukan pelunasan total Pasal 7 ayat (2) huruf b Perjanjian Pembiayaan Kosumen PT. WOM Finance "Apabila penerima fasilitas tidak dapat melunasi seluruh/sisa hutang pembiayaan, maka pemberi fasilitas berhak sebagaimana penerima fasilitas/ pemberi jaminan setuju untuk menarik atau mengambil barang jaminan dan melakukan penjualan, menerima uang hasil penjualan dan memperhitungkan dengan seluruh/ sisa hutang pembiayaan yang masih ada dari penerima fasilitas atau dari pihak lain siapapun yang menguasai barang jaminan tersebut".

Terhadap barang jaminan yang telah dilakukan penarikan dan tidak bisa di selesaikan, Menurut Jasli Litigation Dept. Head PT. WOM Finance "adalah melakukan penjualan terhadap barang jaminan untuk kemudian hasil penjualan akan dipergunakan untuk menutupi sisa hutang penerima fasilitas sesuai dengan kalkulasi yang sudah disepakati” dalam penjualan barang jaminan tersebut, Hasil Penelitian 
Penulis dilapangan terlihat bahwa, ditangani oleh Dept Lelang sebagai salah satu bagian yang ada pada di PT. WOM Finance, penjualan dilakukan kepada dealer motor bekas yang sudah bekerja sama dengan PT. WOM Finance dan kendaraan tersebut dapat di jaminkan lagi sebagai jaminan kebendaan pada perjanjian pembiayaan konsumen PT. WOM Finance yang baru.

Akan tetapi, terkait dengan pendaftaran fidusia tersebut, berdasarkan hasil penelitian dilapangan, penulis menemukan bahwa pendaftaran akta jaminan fidusia oleh PT. WOM Finance Cabang Mataram baru dilakukan 60 hari setelah terjadinya kredit macet dengan alasan untuk menghemat biaya.

Berdasarkan hal itu, Penulis tidak sependapat dengan upaya yang dilakukan oleh PT. WOM Finance Kota Mataram dalam melakukan eksekusi terhadap benda jaminan fidusia, karena tidak sesuai dengan teori keadilan dimana PT WOM Finance melakukan tindakan sewenang- wenangnya yang telah melanggaar asas- asas perjanjian sesuai dengan aturan KUH Perdata, sehingga tidak mewujudkan nilai-nilai keadilan antara pihak debitur dengan kriditur. Karena eksekusi hanya boleh dilakukan terhadap obyek jaminan fidusia yang dalam hal ini dalah debitur yang mengalami kridit macet karena ada unsur kesengajaan, bukan karena keaadaan yang memaksa .

Disampingitu PT. WOM Finance Kota Mataram tidak menggunakan lembaga jaminan fidusia sebagaimana diatur oleh Undang-Undang Nomor 42 tahun 1999 tentang jaminan fidusia karena pengikatan jaminan tidak dilakukan dengan akta otentik sehingga secara langsung juga tidak dapat didaftarkan sebagaimana dimaksud oleh Pasal 5 ayat (1) dan pasal 11 ayat (1) Undang-Undang Fidusia. Karena yang didaftarkan di kantor pendaftaran fidusia hanya akta fidusia yang dibuat notaris dalam bahasa indonesia. Dimana masalah kepatuhan dan ketaatan hukum ini merupakan salah satu factor utama yang menjadi unsur pokok dalam menakar efektif atau tidaknya suatu aturan hukum yang telah ditetapkan karena hal ini sesuai dengan efektifitas hukum dalam masyarakat secara teoritis.

\section{Hambatan-Hambatan Dalam Eksekusi Obyek Jaminan Fidusia Pada PT WOM Finance Mataram}

Menurut Jasli, Litigation Dept. Head PT. WOM Finance Cabang Mataram, hambatan yang seringkali dialami adalah ketika barang jaminan sudah berpindah tangan, tanpa persetujuan tertulis dari PT. WOM Finance Kota Mataram. 
Adapun hambatan-hambatan dalam pengambilan barang jaminan yaitu $:^{15}$

a. Barang jaminan di jual

Penjualan yang di maksud adalah barang jaminan di jual tunai tanpa disertai janji-jani kepada pihak ke-3 oleh penerima fasilitas, dan penerima fasilitas yang dari awal tidak beritikad baik sengaja mengajukan permohonan menjadi penerima fasilitas kemudian barang jaminan tersebut untuk di jual lagi, untuk mendapatkan keuntungan,

b. Barang jaminan di gadaikan.

Proses gadai yang di maksud adalah gadai dibawah tangan antara penerima jaminan dengan pihak ke-3 dengan obyek jaminan adalah barang jaminan dari Perjanjian Pembiayaan Konsumen PT. WOM Finance.

c. Penerima fasilitas tidak mampu lagi

Ketika penerima fasilitas sudah tidak mampu lagi melanjutkan pembayaran angsurannya, penerima fasilitas melakukan oper kredit dengan pihak ke-3 (Over kredit di bawah tangan). Yang dimaksud over ke pihak ke 3 adalah dengan orang yang menguasai sepeda motor, serta yang akan melakukan pemembayar seluruh sisa angsuran sepeda motor kepada PT. WOM Finance Kota Mataram.

${ }^{15}$ Wawancara dengan Jasli, Litigation Dept. Head PT. WOM Finance Cabang Mataram, Pada 13 Mei 2017. d. Pendapatan bulanan penerima jaminan yang tidak menentu

Penerima fasilitas hanya mengandalkan salah satu sumber pendapatan untuk pembayaran angsuransepertitukangojek, sehingga kalau tidak mampu lagi penerima fasilitas mengalihkan barang jaminan tersebut dengan harga yang sangat bervariasi ini tergantung dari jenis, keadaan sepeda motor dan uang muka yang disetor oleh penerima fasilitas kepada pemberi fasilitas sebelum penyerahan barang jaminan.

e. Penerima fasilitas atas nama

Penerima fasilitas atas nama biasanya akan diberi imbalan sejumlah uang Rp. 500.000 sampai Rp. 1.000.000 oleh pihak ke-3 (pengguna barang jaminan) yang memanfaatkan identitas penerima fasilitas.

f. Kurangnya pemahaman penerima fasilitas atas isi Perjanjian Pembiayaan Konsumen dan Perjanjian Pemberian Jaminan Fidusia

Sebagian besar banyak penerima fasilitas dari PT. WOM Finance Kota Mataram yang tidak membaca dengan baik isi dari perjanjian pembiayaan konsumen, perjanjian pemberian jaminan fidusia dan dokumen tambahan lainnya sehingga penerima fasiltas tidak menyadari bahwa mengalihkan barang jaminan tidak merupakan melanggar perjanjian. 
g. Penerima fasilitas pindah Alamat (tidak diketahui)

Penerima fasilitas pindah alamat, kepindahan tersebut tidak di informasikan ke PT. WOM Finance Kota Mataram. Menurut Jasli, Litigation Dept. Head PT. WOM Finance Kota Mataram, "Pindah alamat tanpa diketahui di mana alamat barunya, sangat menyulitkan kami untuk melacak keberaan kendaraan tersebut.

h. Identitas barang telah diubah

Perubahan yang dimaksud adalah seperti nomor mesin dan rangka sepeda motor Yamaha dihapus, sepeda motor yang demikian dikenal dengan sepeda motor bodong.

i. Wilayah kerja Remedial Field dan Dept Collector (DC) yang luas dan krakter masyarakat.

Pada tahun 2017 di Kecamatan Pemenang, Kecamatan Sekotong barat, Kecamatan Obel-Obel yang letaknya masih sulit terjangkau yang merupakan daerah tertinggal dan mengalami satu kendala dalam melakukan penarikanbarangjaminan, yang mana Collector PT. WOM Finance Kota Mataram mangatakan "saya bersama DC di hadang dan diancam oleh masyarakat yang tidak terima dengan penarikan yang di lakukan oleh kami, dengan menutup akses keluar dari kecamatan itu kami di paksa untuk mengembalikan sepeda motor yang telah kami tarik tadi, kami tidak pilihan lagi, dari pada kami dibunuh". ${ }^{16}$

Karakter masyarakat Lombok yang juga keras, yang mengutamakan cara-carakekerasan daripadanegosiasi terhadap barang jaminan hasil pengalihan dari penerima fasilitas, membuat remedial dan dept collector sering mengalami ancaman fisik dan di teriakin maling oleh pemegang terakhir dan orang sekitarnya.

Oleh karena itu, penegakan hukum merupakan upaya yang dilakukan untuk mewujudkan nilai keadilan kemanfaatan dan kepastian hukum terhadap pelaksanaan hukum yang tidak berlangsung baik karena kurangnya ketaatan dan kesadaran terhadap sesuatu yang di tentukan oleh hukum.Sehingga pelaksanaan hukum dapat terjadi di karenakan adanya pelanggaran hukum, dalam hal ini WOM Finance bisa meminta menggunakan alat Negara demi terciptanya penegakan hukum.

${ }^{16}$ Wawancara dengan Nengah Sudiarta, Collector PT. WOM Finance Cabang Mataram, Pada 15 Mei 2017. 


\section{Upaya-Upaya}

Mengatasi

$\mathrm{H}$ a m b a t a n - H a m b a t a n

Pengambilan Kembali Barang Jaminan oleh PT. WOM Finance Kota Mataram.

Menurut Jasli, Litigation Dept. Head PT. WOM Finance Kota Mataram, "Meminta dan melibatkan penerima fasilitas untuk menunjuk kemana barang jaminan di jual untuk kemudian sesuai perjanjian diminta untuk menyerahakan barang jaminan tersebut, apabila langkah diatas tidak berhasil dan ternyata ditemukan adanya unsur pidana, maka perusahaan akan melakukan langkah pelaporan ke Kepolisian atas dugaan telah terjadi tindak pidana oleh customer dengan atau tanpa melibatkan pihak lain". ${ }^{17}$

Adapun langkah sebelum di lakukan pelaporan ke Kepolisan dan yang terus menerus dilakukan adalah $:^{18}$

a. Menawarkan KebijakanBack To Current Account Revieble (BTCA) Back To Remedial

b. Tetap mendatangi penerima fasilitas

c. Mengawasi rumah penerima fasilitas

d. Melibatkan informan tetap atau lepas

${ }^{17}$ Wawancara dengan Jasli, Litigation Dept. Head PT. WOM Finance Cabang Mataram, Pada 13 Mei 2017. Ibid e. Melakukan sweeping

f. Pelaporan kepolisian

\section{KESIMPULAN}

Berdasarkan hasil penelitian dan hasil analisa penulis, maka dapat disimpulkan sebagai berikut :

1. Eksekusi obyek jaminan Fidusia di PT. WOM Finance Kota Mataram dilakukan terhadap customer yang lalai membayarkan hutangnya karena Overmacht dengan pengambilan kembali barang jaminan dari tangan customer maupun di tangan pihak ketiga penerima fasilitas, yang merupakan upaya terakhir PT. WOM Finance Kota Mataram untuk penyelamatan aset dalam upaya meminimalisasi kerugian, apabila customer tidak sanggup lagi melakukan pembayaran angsuran dengan melakukan penjualan barang jaminan, hasil dari penjualan tersebut untuk melunasi sisa hutang penerima fasilitas.

2. Faktor-faktor yang menghambat pelaksanaan Eksekusi obyek jaminan Fidusia Pada PT. WOM Finance Kota Mataram terhadap jaminan fidusia yaitu:

a. Barang jaminan di jualoleh pihak konsumen,

b. barang jaminan di gadaikan,

c. penerima fasilitas tidak mampu lagi, 
d. pendapatan bulanan penerima jaminan yang tidak menentu, penerima fasilitas atas nama,

e. kurangnya pemahaman penerima fasilitas atas isi Perjanjian Pembiayaan Konsumen dan Perjanjian Pemberian Jaminan Fidusia,

f. penerima fasilitas pindah Alamat (tidak diketahui), identitas barang telah diubah, serta.

g. wilayah kerja Remedial Field dan Dept Collector (DC) yang luas dan krakter masyarakat.

\section{DAFTAR PUSTAKA}

Buku

Ahmad Yani \& Gunawan Widjaja, 2000, Jaminan Fidusia, PT. Grafindo Persada, Jakarta.

Fuady, Munir, Jaminan Fidusia (Bandung: PT. Citra aditya, 2000)

Hadisoeprapto, Hartono, 1984, Pokok-Pokok Hukum Perikatan dan Hukum Jaminan, Cet. I, Liberty, Yogyakarta.

J. Satrio, Hukum Jaminan, Hak-hak Kebendaan,, (Bandung: Citra Aditya Bakti, 1991)

Kashadi \& Purwahid Patrik, Hukum Jaminan, 2008 Semarang: Fakultas Hukum, Universitas Diponegoro.
Purwahid Patrik, 1994, Dasar-Dasar Hukum Perikatan (Perikatan yang lahir dari perjanjian dan dari undang-undang), Mandar Maju, Bandung.

Sudikno Mertokusumo, 1998, Hukum Acara Perdata Indonesia, Liberty Jogyakarta.

Wawancara

Amiruddin, Debt Collector. WOM Finance, Rabu 13 Mei 2017

Jasli, Litigation Dept. Head PT. WOM Finance Cabang Mataram, Pada 13 Mei 2017.

Nengah Sudiarta, Collector PT. WOM Finance Cabang Mataram, Pada 15 Mei 2017.

Raden Adi Nugroho, Kepala Cabang PT. WOM Finance, Pada 15 Mei 2017

\section{Undang - Undang}

1. Kitab Undang-Undang Hukum Perdata;

2. Undang-undang Nomor 42 Tahun 1999 tentang Jaminan Fidusia. LEMBARAN NEGARA REPUBLIK INDONESIA TAHUN 1999 NOMOR 168. TAMBAHAN LEMBARAN NEGARA REPUBIK INDONESIA NOMOR 3889.

\section{Internet}

http:// jurnalius.ac.id/ojs/index. $\mathrm{php} /$ jurnalIUS/issue/view/34 